\title{
Decapod crustaceans associated with the shrimp fishery of the central-south portion of Veracruz, Mexico
}

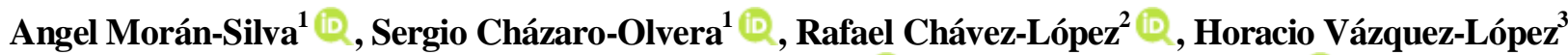 \\ Asela del Carmen Rodríguez-Varela ${ }^{4}$ \& Marcos Mejía-López ${ }^{1}$ \\ ${ }^{1}$ Laboratorio de Crustáceos, Facultad de Estudios Superiores Iztacala \\ Universidad Nacional Autónoma de México, Los Reyes Iztacala, Tlalnepantla \\ Estado de México, México \\ ${ }^{2}$ Laboratorio de Ecología, Facultad de Estudios Superiores Iztacala \\ Universidad Nacional Autónoma de México, Los Reyes Iztacala, Tlalnepantla \\ Estado de México, México \\ ${ }^{3}$ Gestión de Recursos Naturales, Facultad de Estudios Superiores Iztacala \\ Universidad Nacional Autónoma de México, Los Reyes Iztacala, Tlalnepantla \\ Estado de México, México \\ ${ }^{4}$ Laboratorio de Ecología de Peces Estuarinos, Facultad de Estudios Superiores Iztacala \\ Universidad Nacional Autónoma de México, Los Reyes Iztacala, Tlalnepantla \\ Estado de México, México \\ Corresponding author: Angel Morán-Silva (cygamoran@gmail.com)
}

\begin{abstract}
The objective of this study was to analyze the brachyuran crab assemblages associated with shrimp fishing on the central-southern coast of Veracruz. Information was collected using 46 trawls organized within nine fishing quadrants. The total catch shrimp, bycatch, and discard were recorded and standardized $\left(\right.$ CPUE $\mathrm{kg} \mathrm{h}^{-1}$ ). Value index by species, species richness, diversity using Shannon and Weaver index, and equitability were determined. A total of 3055 individuals were collected, which corresponded to nine families, 13 genera, and 14 species. Achelous spinicarpus species were identified at the greatest relative abundance (77.74\%). Four new species records for the zone: Hepatus pudibundus, Iliacantha liodactylus, Leiolambrus punctatissimus, and Platylambrus granulatus. Species richness varied according to fishing quadrant and depth interval assessed. The highest value of species richness was eight, and observed Margalef species richness index values ranged from 0 to 2.23 . The diversity values ranged from 0 to 2.41 bits ind $^{-1}$; this may indicate that a few species share the greatest impact of trawling. The presence of lagoon systems was determined to define a portion of the composition of the assemblage. Understanding assemblage structure is important to improve knowledge on the impact of shrimp trawling activity on the ecosystem.
\end{abstract}

Keywords: brachyuran crabs; abundance; diversity; shrimp fishery; discard; Veracruz

\section{INTRODUCTION}

The shrimp fishery in the Gulf of Mexico is considered the most important generator of resources and infrastructure and produces the fourth-largest catch volume (Wakida-Kusunoki et al. 2006, CONAPESCA 2013). The fishery considerably impacts the ecosystem via bycatch and removal of non-target species. This set of incidentally captured species is known as the shrimp's accompanying fauna (SAF) or bycatch (Grainger \& García 1996). Part of the catch is retained since it is considered useful. At the same time, most accompanying organisms are discarded and returned to the sea since they are either outside the useful commercial size

Corresponding editor: Luis Miguel Pardo 
range or deemed unacceptable due to economic, legal, or cultural factors (McCaughran 1992, Alverson et al. 1994). The catch discard is mainly benthic species, some of which have economic importance in the area (Yañez-Arancibia et al. 1988, Cházaro et al. 2000). Within the discarded component is a group of decapod crustaceans. Importantly, they are the food of other species, including fish of commercial importance (McConnaughey 1974, López-Salgado 1986).

The shrimp fishery in the state of Veracruz is based mainly on the northern brown shrimp (Penaeus aztecus Ives, 1891) catch, which comprises $95 \%$ of the total catch volume, and represented $10 \%$ of the total catch of the Gulf of Mexico throughout 2004 to $2013(217,000$ t) (CONAPESCA 2013). However, the federal government has no detailed or statistical monitoring throughout the last decade for bycatch fauna captures and discard.

The central-south sector of the Veracruz coast, where the fishery is carried out, is markedly influenced by lagoon systems with considerable biological diversity. The system has been subjected to various disturbances that have been the result of anthropogenic activities. Among these, shrimp trawling has been one of the most important (Ruiz et al. 2013). The fishery exists on a continental shelf, at a location containing a decapod crustacean assemblage composed of shrimp, lobster, and crabs (Álvarez et al. 2014). This community is diverse and composed of mainly marine species of all habitats of the continental shelf; many community species are estuarine dependent, so they have the great physiological capacity to withstand salinity changes (Cintra et al. 2017). Additionally, they are considered ecological regulators and are a part of the diet of various fish species (García \& Mendoza 2006). It has been estimated that $16.2 \%$ of the total species of Mexico correspond to the order Decapoda (Álvarez et al. 2014).

Among environmental variables that influence brachyuran crab assemblages composition, distribution and abundance are depth, temperature, and characteristics of the sediment (Lui et al. 2007, Bertini et al. 2010, Ruiz et al. 2013). Further, depth and type of sediment are factors that determine both the biological diversity of the and its distribution (Escobar-Briones \& Jiménez-Guadarrama 2010).

Even though knowledge regarding the composition of the brachyuran crab assemblages in the area is available, understanding its interaction with shrimp fishing in the central-southern portion of Veracruz is scarce since most previous studies have been inventories and taxonomic studies (Gómez-Lemos et al. 2010). The fishing activity involves removing species due to shrimp trawling and the low selectivity of fishing nets. These activities impact community structure and alter the distribution patterns of species (Morán-Silva et al. 2017). Accordingly, the objective of this study was to analyze the brachyuran crab assemblages associated with shrimp fishing in the central-southern sector of the Veracruz coast and determine its variation across different zones and trawling depths.

\section{MATERIALS AND METHODS}

The area assessed via shrimp trawling was located on the continental shelf of the southwestern section of the Gulf of Mexico and extended from the port of Alvarado $\left(18^{\circ} 47^{\prime} 42.94^{\prime \prime} \mathrm{N}, 95^{\circ} 44^{\prime} 43.87^{\prime \prime} \mathrm{W}\right)$ to the port of Coatzacoalcos $\left(18^{\circ} 10^{\prime} 50.16^{\prime \prime} \mathrm{N}, 94^{\circ} 25^{\prime} 11.51 " \mathrm{~W}\right)$ in the state of Veracruz (Fig. 1). The continental shelf within the region is characterized by its marked continental influence, which results from extensive estuarinelagoon systems. These are mainly from the Papaloapan River and the Alvarado Lagoon System (ALS). This deltaic system has an important role in contributing terrigenous elements and organic matter to the shelf (Contreras 1993, Morán-Silva et al. 2005). The type of sediment present in the fishing area is dominated by flat bottoms and a considerable amount of mud and sand. Since discharge from the estuarine-lagoon systems occurs, irregular bottoms composed of highly consolidated sediments and rocky bottoms, marine and coastal-alluvial origin materials were also observed (Jiménez 1979, González-Gándara 2011).

According to García (1982), the climate of the study area is described as a sub-humid, hot climate, rainfall between June and September varies between 1100 and $2000 \mathrm{~mm}$, and the average annual temperature is $26.4^{\circ} \mathrm{C}$, with maximum and minimum values of 22.6 and $29.3^{\circ} \mathrm{C}$, respectively. The climatic pattern of the zone prompted researchers to define three climatic seasons, as follows: cold front: October to February; dry: March to May, and rainy: June to September (Morán-Silva et al. 2005).

Shrimp trawling was carried out in July and occurred concurrently with research cruises carried out by the Veracruz-INAPESCA Regional Center for Fisheries Research. The location of trawling was established under the criteria of the National Fisheries Institute (Fig. 1) (SAGARPA-INAPESCA 2010), which divided the Veracruz coast into quadrants corresponding to the bathymetric profile of two depth intervals: $\mathrm{B}: 22$ to $46 \mathrm{~m}$; and C: $>46 \mathrm{~m}$. The trawls were located within nine quadrants, which comprised depth intervals $\mathrm{B}$ and $\mathrm{C}$. According to their geographical location, quadrants were identified on the northwestsoutheast axis, extending from the Alvarado port to Coatzacoalcos. Quadrants were located along with 


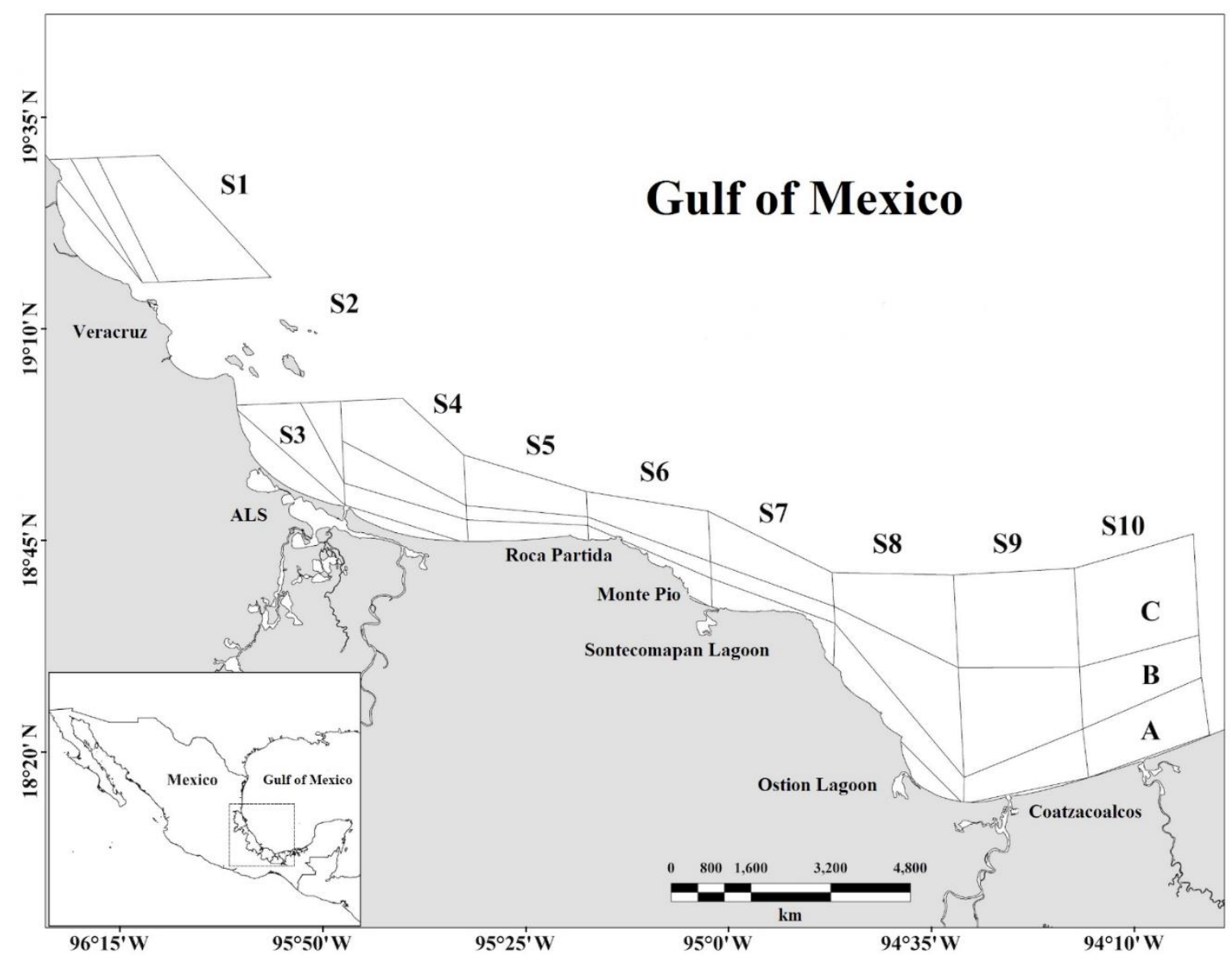

Figure 1. Study area (taken from SAGARPA-INAPESCA (2010)).

different estuarine-lagoon systems along the coast and possessed different geomorphological features (Fig. 1).

The information garnered from 46 trawls located and organized within nine fishing quadrants (S1B, S3B, S4B, S7B, S4C, S5C, S6C, S7C, and S8C) was analyzed. The draws corresponding to interval $\mathrm{B}$ were composed of four quadrants (with the number of trawls by quadrant) S1B (1), S3B (8), S4B (6), and S7B (6), and those of interval $C$ included five quadrants $\mathrm{S} 4 \mathrm{C}(4)$, S5C (5), S6C (4), S7C (4) and S8C (8) (Fig. 1). Organisms were caught throughout commercial fishing operations carried out on shrimp vessels of the commercial fleet of the port of Alvarado, Veracruz, which used $20 \mathrm{~m}$ Japanese multi-fishing trawls with 9 m openings and meshed spanning 1.75". Trawling was performed at night, lasting from 2 to $6 \mathrm{~h}$, and a speed of 3 knots per hour.

Onboard the vessel, the total catch shrimp, SAF, and discard, which was made up of all vertebrate and invertebrate species returned to the sea, was recorded in kilograms with the help of a CRS200 model hanging scale with a capacity of $200 \mathrm{~kg}$. Catch weights were standardized to reflect the catchweight per unit fishing effort (CPUE $\mathrm{kg} \mathrm{h}^{-1}$ ) using the swept area method (Sparre \& Venema 1995). A $4 \mathrm{~kg}$ sample of organisms from the discarded catch of each trawl was collected to analyze the brachyuran crab assemblages (GiménezHurtado et al. 2016).

Collected organisms were washed, placed in polyethylene bags, and frozen. In the laboratory, organisms were identified using the criteria described by Williams (1966), Felder (1973) and Hernández-Aguilera \& SosaHernández (1982) following the phylogenetic classification system proposed by Glaessner (1969). Individuals were weighed using a balance. Each individual's weight, sex, and maturity were determined by evaluating the abdomen and telson (Williams 1974). The carapace's width $(\mathrm{CW})$ and carapace length (CL) were measured using a vernier caliper to $0.1 \mathrm{~mm}$ precision.

The Shapiro-Wilk normality test was applied to evaluate each data set (Sokal \& Rohlf 2003). Afterward, the abundance of each captured species and measures of central tendency and dispersion per fishing 
quadrant were determined. The composition was determined for each fishing quadrant by estimating the importance value index for each species (IVI), which involved the sum of the relative abundance, frequency, and dominance values and indicated the relative ecological importance of species within the community (Matteucci \& Colma 1982). Species richness was determined using the Margalef richness index, and diversity values were obtained using the Shannon and Weaver index (Margalef 1974). Richness concerning the number of species observed and their equitability (Magurran \& McGill 2011) was determined using the PRIMER v.6 software program (Hammer \& Harper 2003). A one-way analysis of variance (ANOVA) was applied (Sokal \& Rohlf 2003) to compare fishing quadrants. Classification analysis was applied using Jaccard similarity analysis and the Silhouette coefficient in PRIMER v.6 to determine if the species composition revealed variation between quadrants (Hammer \& Harper 2003, Chávez-López et al. 2005) according to Magurran \& McGill (2011). In addition to grouping sites based on abundances of species management analyses, non-parametric multidimensional scaling (nMDS), rather than metric scaling, was applied (Warwick \& Clarke 1991).

\section{RESULTS}

Data describing discarded catches were normally distributed $(P>0.05)$. Shrimp catch and shrimp's accompanying fauna (SAF) data were non-normally distributed $(P<0.05)$, however. Average CPUE kg h${ }^{-1}$ values for shrimp, SAF, and discarded organisms by quadrant were determined (Table 1).

The greatest volume shrimp catch was recorded from depth interval B, S7B quadrant, and produced $37.50 \mathrm{~kg} \mathrm{~h}^{-1}$ shrimp. The quadrant was located in front of the Sontecomapan Lagoon. The catch lowest volume catch was recorded in quadrants S7C and S4C, which each produced $1.50 \mathrm{~kg} \mathrm{~h}^{-1}$ shrimp from interval depth C. The average shrimp catch volumes $\left(\mathrm{kg} \mathrm{h}^{-1}\right)$ determined by quadrant were determined to be significantly different $(P<0.005)$. The greatest volume of SAF was collected from quadrant S6C $\left(86.12 \mathrm{~kg} \mathrm{~h}^{-1}\right)$, which was located in front of Roca Partida. The SAF lowest quantity was collected from quadrant S3B, located in front of the Alvarado Lagoon System. The average SAF value for interval B was $21.66 \pm 12.42 \mathrm{~kg}$ $\mathrm{h}^{-1}$, while for interval $\mathrm{C}$, it was $24.93 \pm 15.77 \mathrm{~kg} \mathrm{~h}^{-1}$. SAF values determined by quadrants were determined to be significantly different $(P<0.05)$. On the other hand, the highest and lowest quantity of discarded catch were determined to occur in quadrant S7B $(110.00 \mathrm{~kg}$ $\mathrm{h}^{-1}$ ) and S8C $\left(23.38 \mathrm{~kg} \mathrm{~h}^{-1}\right)$, respectively. An average catch of $64.91 \pm 18.35$ and $43.54 \pm 14.77 \mathrm{~kg} \mathrm{~h}^{-1}$ was determined for intervals $\mathrm{B}$ and $\mathrm{C}$, respectively, and the differences between average values determined for each fishing quadrant were statistically significant $(P<$ 0.05) (Table 1). The shrimp catch records highlighted some quadrants with the highest presence of bycatch, highlighting the quadrants in front of lagoon systems, such as the SLA and the Sontecomapan Lagoon.

A total of 3055 brachyurans were collected throughout 46 trawls. Individuals identified belonged to 9 families, 13 genera, and 14 species. The decapod crustacean that was most dominant was from the family Portunidae $(80.33 \%)$, followed by the families Leucosiidae $(9.30 \%)$ and Inachoididae $(6.25 \%)$ (Table 2). Species present at the greatest relative abundance included Achelous spinicarpus Stimpson, 1871 (77.74\%), Iliacantha liodactylus Rathbun, 1898 (9.30\%), Anasimus latus Rathbun, 1894 (6.25\%) and Achelous gibbesii (Stimpson, 1859) (2.59\%) (Table 2). Five species were determined to have the greatest IVI values. These included A. spinicarpus $(49.20 \%), I$. liodactylus (14.04\%), A. latus (11.34\%), A. gibbesii (6.93\%), and Hepatus pudibundus (Herbst, 1785) $(5.28 \%)$. The remaining nine species had IVI values that collectively accounted for $13.21 \%$ of the total (Table 2).

Four new recorded species were identified in the study area. It included Hepatus pudibundus (quadrants S3B, S4B, S4C, S5C, S6C, S7C, and S8C), I. liodactylus (quadrants S3B, S4B, S4C, S5C, S6C, S7B, S7C, and S8C), Leiolambrus punctatissimus (Owen, 1839) (quadrants S3B, S4B, S4C, S5C, S6C, S7B, and S8C) and Platylambrus granulatus (Kingsley, 1879) (quadrants S3B, S4C, S6C, S7B, and S8C). Species richness varied according to fishing quadrant and depth interval assessed. The highest value was recorded within quadrant S3B (eight species), while the lowest value (one species) was reported for quadrant S4C (Fig. $2 a)$. In addition, average richness values determined by quadrants were statistically distinct $(P=0.0419)$.

Margalef species richness index values (Fig. 2b) ranged from 0 to 2.23 (quadrants $\mathrm{S} 4 \mathrm{C}$ to $\mathrm{S} 3 \mathrm{~B}$, respectively). The average values obtained for the quadrants were determined to be significantly different $(P=0.0016)$. Diversity values $\left(\mathrm{H}^{\prime}\right)($ Fig. $2 \mathrm{c})$ ranged from 0 (S4C) to $2.41 \mathrm{bits}^{\mathrm{ind}^{-1}}(\mathrm{~S} 3 \mathrm{~B})$, and average values determined for each quadrant were determined to be statistically different $(P=0.0004)$.

The dendrogram obtained using similarity index data produced two blocks (Silhouette coefficient = 0.863 ). The first was composed of the S1B quadrant in which the lowest species richness was registered $(\mathrm{S}=$ 2). The quadrant was located north of the Veracruz Reef System (SAV) that mirrored the mouth of the La 
Table 1. Minimum (Min), maximum (Max), mean, and standard deviation (SD) of shrimp CPUE values ( $\left.\mathrm{kg} \mathrm{h}^{-1}\right)$, shrimp's accompanying fauna (SAF), and discard (DISC) by quadrant (ID).

\begin{tabular}{|c|c|c|c|c|c|c|c|c|c|c|c|c|}
\hline \multirow{2}{*}{ ID } & \multicolumn{4}{|c|}{ Shrimp } & \multicolumn{4}{|c|}{ SAF } & \multicolumn{4}{|c|}{ DISC } \\
\hline & Min & Max & Mean & SD & Min & Max & Mean & SD & Min & Max & Mean & SD \\
\hline S1B & - & - & 1.500 & 0.0000 & - & - & 70.250 & 0.0000 & 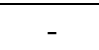 & - & 60.000 & 0.0000 \\
\hline S3B & 12.89 & 37.18 & 27.094 & 8.6843 & 60.11 & 97.67 & 72.069 & 13.0798 & 45.56 & 85.71 & 58.060 & 14.0142 \\
\hline S4B & 3.50 & 25.00 & 13.810 & 7.6343 & 71.37 & 129.70 & 101.515 & 19.7608 & 62.11 & 92.50 & 79.157 & 11.7208 \\
\hline S7B & 2.00 & 37.50 & 11.012 & 13.3274 & 69.77 & 135.90 & 101.145 & 27.9700 & 40.57 & 110.00 & 67.595 & 24.8029 \\
\hline $\mathrm{S} 4 \mathrm{C}$ & 1.50 & 10.00 & 6.698 & 3.7959 & 53.54 & 84.25 & 73.198 & 13.6394 & 41.54 & 66.00 & 56.358 & 10.4587 \\
\hline S5C & 6.00 & 11.90 & 9.424 & 2.4847 & 48.23 & 97.80 & 70.082 & 22.5012 & 28.76 & 72.50 & 48.640 & 19.1775 \\
\hline S6C & 3.60 & 33.33 & 7.990 & 3.0154 & 54.45 & 134.12 & 83.525 & 34.8380 & 35.20 & 50.00 & 45.030 & 6.6764 \\
\hline S7C & 9.23 & 14.12 & 10.740 & 2.2752 & 55.28 & 93.85 & 69.848 & 16.6873 & 55.28 & 66.50 & 41.883 & 17.7592 \\
\hline S8C & 10.00 & 13.28 & 11.724 & 1.1927 & 40.00 & 90.80 & 58.089 & 19.4116 & 23.38 & 64.00 & 36.826 & 12.3315 \\
\hline
\end{tabular}

Table 2. Families and species of brachyuran crabs making up the discard fauna of shrimp trawls in the central-southern area of Veracruz. n: number of individuals; RF: relative frequency; RD: relative dominance; IVI, importance value index; WC: width carapace $(\mathrm{cm})$; LC: length carapace $(\mathrm{cm})$; W: weight $(\mathrm{g}) ; \mathrm{F}: \mathrm{M}$ : sex ratio (females:males).

\begin{tabular}{|c|c|c|c|c|c|c|c|c|}
\hline Family/Species & $\mathrm{n}$ & $\mathrm{RF}$ & $\mathrm{RD}$ & IVI & WC & LC & $\mathrm{W}$ & $\mathrm{F}: \mathrm{M}$ \\
\hline \multicolumn{9}{|l|}{ Calappidae } \\
\hline Hepatus epheliticus (Linnaeus, 1763) & 2 & 0.94 & 0.07 & 0.5 & & & & $1: 1$ \\
\hline Hepatus pudibundus (Herbst, 1785) & 36 & 9.39 & 1.18 & 5.28 & $2.0-9.8$ & $1.5-6.8$ & $1.0-145.8$ & 1:0.15 \\
\hline \multicolumn{9}{|l|}{ Inachidae } \\
\hline Coryrhynchus sidneyi (Rathbun, 1924) & 2 & 0.94 & 0.07 & 0.5 & $0.8-1.0$ & $1.4-1.1$ & $0.4-0.8$ & $1: 1$ \\
\hline Stenorhynchus seticornis (Herbst, 1788) & 2 & 0.94 & 0.07 & 0.5 & $1.3-2.0$ & $2.7-4.3$ & $1.5-2.7$ & $1: 1$ \\
\hline \multicolumn{9}{|l|}{ Inachoididae } \\
\hline Anasimus latus Rathbun, 1894 & 191 & 16.4 & 6.25 & 11.34 & $0.7-2.8$ & $1.0-3.3$ & $0.1-5.7$ & $1: 0.82$ \\
\hline \multicolumn{9}{|l|}{ Leucosiidae } \\
\hline Iliacantha liodactylus Rathbun, 1898 & 284 & 18.8 & 9.3 & 14.04 & $1.0-22$ & $1.02-5.5$ & $0.3-9.8$ & $1: 0.55$ \\
\hline \multicolumn{9}{|l|}{ Epialtidae } \\
\hline Stenocionops furcatus (Olivier, 1791) & 2 & 0.94 & 0.07 & 0.5 & $2.4-6.7$ & $3.6-8.0$ & $6.4-65.3$ & $1: 1$ \\
\hline \multicolumn{9}{|l|}{ Parthenopidae } \\
\hline Leiolambrus punctatissimus (Owen, 1839) & 27 & 4.69 & 0.88 & 2.79 & $1.4-2.3$ & $0.7-1.5$ & $0.5-3.0$ & 1:0.66 \\
\hline Platylambrus granulatus (Kingsley, 1879) & 22 & 5.63 & 0.72 & 3.18 & $1.2-3.0$ & $1.2-1.8$ & $0.9-4.2$ & 1:0.69 \\
\hline \multicolumn{9}{|l|}{ Portunidae } \\
\hline Achelous spinicarpus Stimpson, 1871 & 2375 & 20.7 & 77.7 & 49.2 & $0.2-39$ & $0.4-18$ & $0.4-47$ & $1: 0.43$ \\
\hline Achelous gibbesii (Stimpson, 1859) & 79 & 11.3 & 2.59 & 6.93 & $3.0-7.7$ & $1.3-6.0$ & $2.7-65.7$ & $1: 1.13$ \\
\hline Callinectes similis Williams, 1966 & 23 & 5.16 & 0.75 & 2.96 & $5.0-11$ & $2.4-5.0$ & $4.6-78$ & 1:0.64 \\
\hline \multicolumn{9}{|l|}{ Pseudorhombilidae } \\
\hline Pseudorhombila quadridentata (Latreil & 3 & 1.41 & 0.1 & 0.75 & $3.3-4.2$ & $2.5-3.5$ & $9.2-32$ & $1: 0.5$ \\
\hline
\end{tabular}

Antigua river. It should be noted that the area was not considered to be within normal shrimp fishing grounds. The second block was subdivided into three groups. Of these, quadrant S4C stood out due to its use as a major shrimp fleet fishing area, located opposite the mouth of the ALS. Within the quadrant, 11 species were identified. The next group within the block was comprised of quadrants S8C, S3B, and S4B. The group was influenced by the mouth of the Coatzacoalcos River and the ALS. From quadrants, S8C, S3B, and S4B, 9, 10, and 11 species were identified, respectively, and the group was made up of depth intervals $\mathrm{C}$ and $\mathrm{B}$.
Finally, the third group was composed of quadrants S7C, S7B, S5C, and S6C and was located throughout Roca Partida to the vicinity of the Ostión Lagoon. The region was the second-most important fishing area to the shrimp fleet based at the port of Alvarado and, except for the S7B quadrant, was within depth interval $\mathrm{C}$, and quadrants had richness values that ranged from seven to nine species (Fig. 3).

The diagram produced using non-parametric multiple dimensional scaling test (nMDS) data was based on similarities calculated using the Bray-Curtis index and average specific richness values for each of 


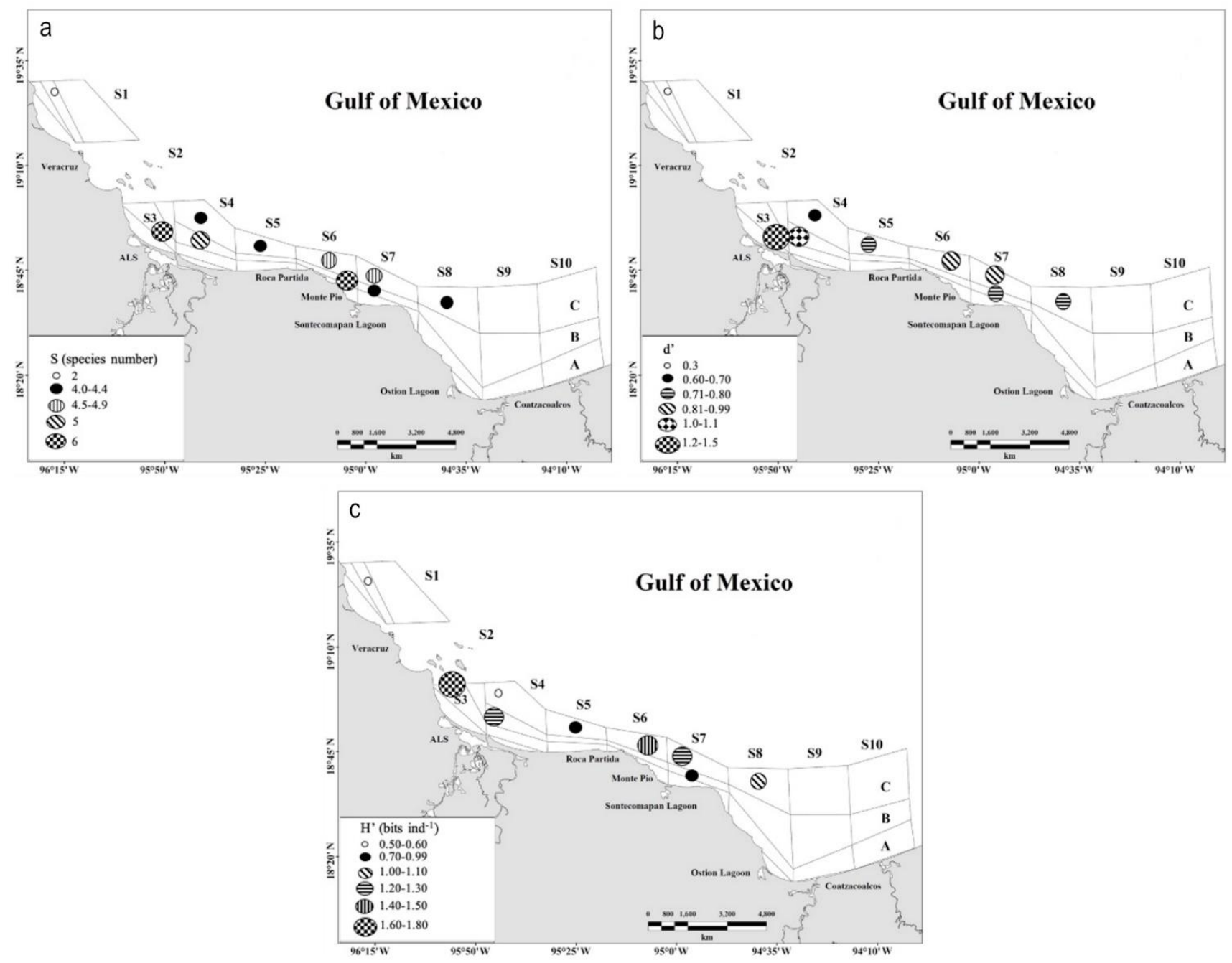

Figure 2. Community parameters of the brachyuran crab assemblages by quadrant that correspond to the discard fauna of shrimp trawls in the central-southern area of the state of Veracruz. a) Richness (species number), b) d': Margalef's specific richness, c) H': Shannon-Weaver diversity $\left(\right.$ bits ind $^{-1}$ ).

the nine quadrants. Two major groupings were obtained using this method.

The first group corresponded to the S1B quadrant, and the second grouping was subdivided into two blocks. The first block included a pair of similar quadrants (S7C and S6C), corresponding to the outer part of the transect, with depths greater than $25.5 \mathrm{~m}$, characterized by the low influence of discharges and low trawling activity. The second block contained six quadrants (S4C, S3B, S4B, S7B, S8C, S5C, and S6C) characterized by being an area influenced by the discharge of the ALS and the Sontecomapan Lagoon; it is one of the main trawling grounds for the fleet in the port of Alvarado (Fig. 4).

\section{DISCUSSION}

According to Ruiz et al. (2013), most studies assessing the macroinvertebrate community of the southwestern Gulf of Mexico have focused on commercial importance species. Of these, taxonomic lists of brachyuran crabs associated with shrimp trawling areas predominate (Vázquez-Bader \& Gracia 1994, Cházaro et al. 2000, Rodíguez-Almaraz et al. 2000, GarcíaMadrigal et al. 2002, Wicksten \& Packard 2005, Huidobro-Campos et al. 2021). Shrimp trawling activity is typically carried out within soft-bottom habitats. It is associated with coastal areas near discharge from estuarine-lagoon systems, which are habitats used by these species as breeding areas (Wells et al. 2008). 


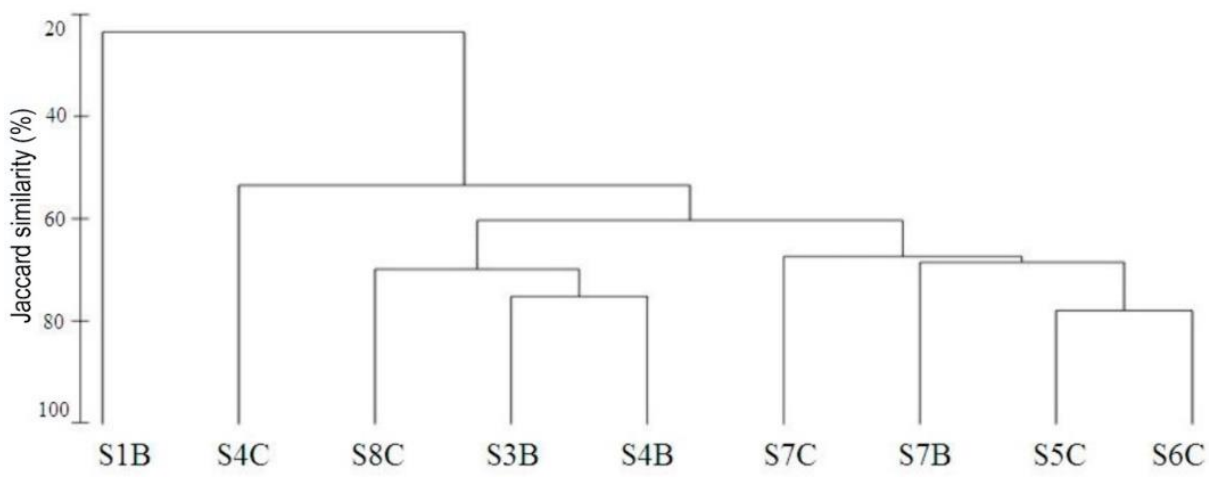

Figure 3. Dendrogram of the relative abundance of decapod crustaceans that make up the discard fauna of shrimp trawls in Veracruz central-southern area.

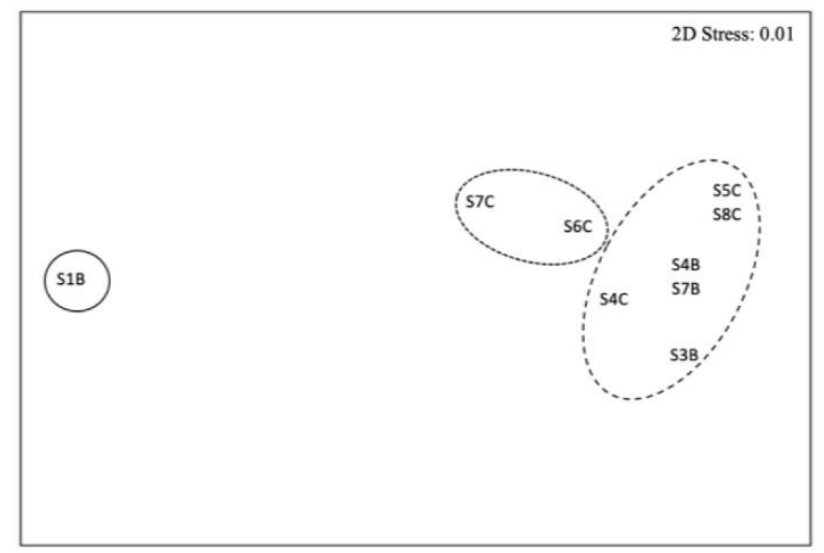

Figure 4. Analysis of non-parametric multidimensional scaling (nMDS) of the relative abundance of brachyuran crab assemblages that make up the shrimp trawls discard fauna in Veracruz central-southern area.

The shrimp, accompanying fauna, and discarded species obtained in the present study were associated with depth intervals and trawl areas, and the average volume of the shrimp catch $\left(17.48 \mathrm{~kg} \mathrm{~h}^{-1}\right)$ was then that which was recorded in Scott-Denton et al. (2007) for the northern Gulf of Mexico (9.6 $\left.\mathrm{kg} \mathrm{h}^{-1}\right)$. Likewise, significant differences were observed in the averages of shrimp catches between the two depth intervals and between the fishing quadrants, which determines areas with different fish production, indicating that depth is a factor affecting the catch volume of other quadrants. This finding coincided with previous work by WakidaKusunoki et al. (2013). The researchers assessed shrimp trawls throughout the closed season in the NE portion of the Gulf of Mexico. Differences between the fishing quadrants corresponded to trawling depth, followed by spatial location and proximity to lagoon systems. Lagoon systems were reported to be important factors because the systems provide breeding areas for various species of crustaceans and fish. Yañez-
Arancibia (1986) reported an increase in catch and species richness during the closed season.

Discard catch volume predominated total catch volumes and was composed of both juvenile and adult size organisms. Therefore, the Veracruz coast continental shelf can be considered an area where target and non-target species share habitats and behavioral patterns that overlap, making the capture of non-target individuals inevitable (Wells et al. 2008).

The determination of the composition of organisms provided important information regarding the structure of assemblages associated with shrimp-trawling areas throughout southern Veracruz. The number of species recorded in the present study was lower than that reported by Vázquez-Bader \& Gracia (1994) for the southeastern portion of the Gulf of Mexico; HermosoSalazar \& Arvizu-Coyotzi (2007) for the state of Veracruz; Scott-Denton et al. (2007) for the northern Gulf of Mexico; and Giménez-Hurtado et al. (2016) for the southeastern platform of Cuba. Previous studies assessed species of the Portunidae family, including those determined to be highly dominant in the present study in which A. spinicarpus was determined to be most highly dominant $(77.74 \%)$ and its relative frequency value was determined to be $20.66 \%$. Likewise, Bertini \& Fransozo (2004) found that $A$. spinicarpus was extremely abundant throughout the 35 $\mathrm{m}$ isobath, matching with the present study findings. Similarly, Sanvicente-Añorve et al. (2008) reported that the species was the second-most important member in the abundance of the Portunidae family within the southeast portion of the Gulf of Mexico, indicating that the greatest impact of trawling is shared by a few species, as reported by Giménez-Hurtado et al. (2016). According to Gracia \& Mendoza (2006), effects on the ecosystem occur since affected species contributing significantly to capture biomass are comprised species forage from higher trophic levels. For instance, they are food sources of demersal fish. 
Because composition and abundance are directly related to species of the Portunidae family, the structure of assemblage is dependent on the family, in accordance with data reported by Setubal-Pires (1992), who determined that, for shrimp trawling areas of Brazil, Achelous spinimanus (Latreille, 1819) contributes considerably to abundance and biomass values, which affect community structure and are considered to be the most important species affecting the soft-bottom, benthic community. Therefore, the role of crustaceans in the functioning of the ecosystem is relevant, mainly as a result of their position in the trophic chain, in which the function to transform organic matter into proteins, which are consumed by organisms of higher trophic levels, such as demersal fish (García-Madrigal et al. 2012).

For the Alvarado fishing zone, Cházaro et al. (2000) report that Callinectes similis Williams, 1966 were the dominant species identified, followed by A. gibbesii, $A$. spinicarpus, Calappa sulcata Rathbun, 1898, Hepatus epheliticus (Linnaeus, 1763) and Anasimus latus Rathbun, 1894. Differences between previous studies and this one may result from the fact that shrimp trawlers covered a greater area in the current study, spanned from Veracruz Port to Coatzacoalcos Port. Further, this allowed researchers to obtain a greater number of trawls and sample different depth intervals and areas, which resulted in an improved characterization of the community and an expansion of the distributions of some species.

Powers (1977) registered 47 species within the study area, while Vázquez-Bader \& Gracia (1994) identified 43 species within the same area. According to Álvarez et al. (1999), brachyuran crabs of the present study included 14 species, which had an affinity for tropical waters and a wide distribution. The distribution range of four species was extended to include the central-south portion of the Veracruz coast. These species included Hepatus pudibundus, I. liodactylus, $L$. punctatissimus and $P$. granulata.

The present study results make it possible to differentiate composition patterns for brachyuran crabs and the different fishing and depth quadrants, distributed from north to south where both common fishing areas and trawling activity are minimal. Thus, allowing researchers to observe distinct patterns of habitat use (Wells et al. 2008).

Diversity determined in the present study was assessed concerning similar assemblages associated with shrimp trawling areas in the Gulf of Mexico. Vázquez-Bader (1988) found that diversity values at different depths and different substrates varied from 2 to 4.4. However, Wells et al. (2008) found that average diversity values for shrimp trawl areas in the north- eastern portion of the Gulf of Mexico were between 1.72 and 1.85 bits ind $^{-1}$. Similarly, in the southwest of Brazil, shrimp trawl areas (Bertini \& Fransozo 2004) were characterized by estuarine-lagoon systems and soft-bottom habitats, allowing the development of a trawl shrimp fishery, values ranging from 0.72 to 2.51 bits ind ${ }^{-1}$ were identified. Values determined in the present study were highly variable, likely due to the high degree of dominance of three species that affected values determined and produced low equitability values.

Diversity estimates similar to those found in the present study have been reported for the northern Gulf of Mexico. Chittenden \& McEachran (1976) determined that values of diversity and uniformity within sand habitats in NW Gulf varied from 0.293 to 2.59 bits ind $^{-1}$, while Chittenden \& Moore (1977) determined that the average diversity was 2.62 bits ind $^{-1}$ over the $110 \mathrm{~m}$ bathymetric contours of the NW portion of the Gulf of Mexico.

Groupings obtained from similarity index and nMDS data revealed defined ways that depth intervals and geographical locations affected values. Therefore, lagoon systems were determined to define a portion of the assemblage composition, allowing us to establish that some quadrants were similar in species composition, possibly due to their depth interval and geographic location.

Studies investigating brachyuran crabs in the Gulf of Mexico have mainly focused on species of commercial importance (Ruiz et al. 2013, HuidobroCampos et al. 2021). They have left out species that are of no commercial value. Therefore, their impact on the benthic communities of the southeast sector of the Gulf of Mexico, which is an important shrimp trawling area, has not been determined. Specifically, the importance of habitats used for breeding and, as described in Wells et al. (2008), carbon transfer affects species of higher trophic levels, such as fish (Morán-Silva et al. 2017) have not been assessed.

Results obtained in this study suggested that the composition and structure of the brachyuran crab assemblages are affected by their depth intervals and lagoon systems throughout the fishing zone. Further, the dominance of a few species also affects community structure. These findings are in line with data reported by Gómez-Lemos et al. (2010), who showed that depth was one of the main factors that affected the composition of the assemblage.

Shrimp trawling activities were determined to modify assemblage structure by extracting several species, which were discarded. Therefore, it is important to understand the degree to which trawling impacts the seabed by assessing its composition and assemblage 
structure. As mentioned by Gracia et al. (1997), the impact of trawling can be damaging. It can alter assemblage structure and species abundance by constantly removing species considered accompanying fauna.

Species richness, relative abundance, diversity, and catch volumes analyzed in this study are important parameters, which can be used to characterize features of the assemblage and assess the impact of shrimp trawling activities that occur throughout the centralsouth portion of the Veracruz coast. However, constant monitoring of the assemblage is necessary to accurately determine the impact of fishing activity and establish zones that facilitate the growth and development of the decapod crustacean community.

\section{ACKNOWLEDGMENTS}

The authors thank the support given by VeracruzINAPESCA Regional Center for Fisheries Research in obtaining the samples. To the shrimp fleet of the port of Alvarado, Veracruz, for allowing us to participate in shrimp fishing 2013 season. To the National Council of Science and Technology (CONACYT) for the support through the National System of Researchers, request 154192 .

\section{REFERENCES}

Álvarez, F., Villalobos, J.L., Rojas, Y. \& Robles, R. 1999. Listas y comentarios sobre los crustáceos decápodos de Veracruz, México. Anales del Instituto de Biología, Serie Zoología, 70: 1-27. [http://revistas.unam.mx/ index.php/zoo/article/view/7216]. Reviewed: November 8, 2019.

Álvarez, F., Villalobos, J.L., Hendrickx, M.E., EscobarBriones, E., Rodríguez-Almaraz, G. \& Campos, E. 2014. Biodiversidad de crustáceos decápodos (Crustacea: Decapoda) en México. Revista Mexicana de Biodiversidad, 85: 208-219. doi: 10.7550/rmb.38758

Alverson, D.L., Freeberg, M.H., Pope, J.G. \& Murawski, S.A. 1994. A global assessment of fisheries bycatch and discards. FAO Fisheries Technical Paper, 339: 233 pp.

Bertini, G. \& Fransozo, A. 2004. Bathymetric distribution of brachyuran crab (Crustacea, Decapoda) communities on coastal soft bottoms off southeastern Brazil. Marine Ecology Progress Series, 279: 193-204. doi: 10.3354/meps279193

Bertini, G., Fransozo, A. \& Negreiros-Fransozo, M.L. 2010. Brachyuran soft-bottom assemblage from marine shallow waters in the southeastern Brazilian littoral.
Marine Biodiversity, 40: 277-291. doi: 10.1007/s125 26-010-0049-9

Cházaro, O.S., Rocha-Ramírez, A. \& Román-Contreras, R. 2000. Observations on feeding, maturity, and fecundity of Callinectes similis Williams, 1966, on the central continental shelf off Veracruz, Gulf of Mexico. Crustaceana, 73: 323-332. doi: 10.1163/15685400050 4417

Chávez-López, R., Franco-López, J., Morán-Silva, A. \& O'Connell, M.T. 2005. Long-term fish assemblage dynamics of the Alvarado Lagoon Estuary, Veracruz, Mexico. Gulf and Caribbean Research, 17: 145-156. doi: $10.18785 /$ gcr.1701.15

Chittenden, M.E. \& McEachran, J.D. 1976. Composition, ecology, and dynamics of demersal fish communities on the northwestern Gulf of Mexico continental shelf, with a similar synopsis for the entire Gulf. Sea Grant Publication, Texas A\&M University, Texas.

Chittenden, M.E. \& Moore, D. 1977. Composition of the ichthyofauna inhabiting the 110-meter bathymetric contour of the Gulf of Mexico, Mississippi River to the Rio Grande. Northeast Gulf Science, 1: 106-114. doi: 10.18785/negs.0102.06

Cintra, I.H.A., De Sá Paiva, K., Herrmann, M., Barbosa, J.M., De Macedo-Klautau, A.G. \& Araújo-Silva, K.C. 2017. Carcinofauna acompanhante do camarão-rosa em pescarias industriais na plataforma continental amazônica. Acta of Fisheries and Aquatic Resources, 5: 69-77. doi: 10.2312/Actafish.2017.5.2.83-91

Comisión Nacional de Acuacultura y Pesca (CONAPESCA). 2013. Anuario estadístico de acuacultura y pesca 2013. Secretaría de Agricultura, Ganadería, Desarrollo Rural, Pesca y Alimentación, Ciudad de México. [http://www.conapesca.sagarpa.gob.mx/wb/ cona/anuario_2013]. Reviewed: October 14, 2018.

Contreras, F. 1993. Ecosistemas costeros mexicanos. Universidad Autónoma Metropolitana, Unidad Iztapalapa, Ciudad de México.

Escobar-Briones, E. \& Jiménez-Guadarrama, E.L. 2010. Macrocrustáceos (Peracarida, Decapoda) de fondos carbonatados del sector occidental del banco de Campeche en el sur del golfo de México. Revista Mexicana de Biodiversidad, 81: 63-72.

Felder, D.L. 1973. An annotated key to crabs and lobsters (Decapoda, Reptantia) from coastal waters of the northwestern Gulf of Mexico. Center for Wetland Resources, Louisiana State University, Sea Grant Publication LSU-SG-73-02, Baton Rouge, Louisiana.

García, E. 1982. Modificaciones al sistema de clasificación climática de Köppen: para adaptarlo a las condiciones de la República Mexicana. Universidad Nacional Autónoma de México, Ciudad de México. 
García, B.C. \& Mendoza, N. 2006. Aspectos de la biología de Portunus spinicarpus Stimpson 1871 (Decapoda: Portunidae) en el Golfo de Salamanca, Caribe colombiano. Boletín de Investigaciones Marinas y Costeras, 35: 235-239.

García-Madrigal, M.S., Campos-Vázquez, C. \& González, N.E. 2002. Sección de crustáceos de la colección de referencia de bentos costero de ecosur. Universidad y Ciencia, 36: 140-148. doi: 10.19136/era.a18n36.233

García-Madrigal, M.S., Villalobos-Hiriart, J.L., Álvarez, F. \& Bastida-Zavala, R. 2012. Estado del conocimiento de los crustáceos de México. Ciencia y Mar, 16: 43-62.

Giménez-Hurtado, E., Caridad-Pérez, A., Delgado-Miranda, G., Domínguez, H.A. \& Villafuerte-Delgado, V. 2016. Comportamiento de la fauna acompañante en la pesca de camarón rosado (Farfantepenaeus notialis) en la plataforma suroriental de Cuba. REDVET Revista Electrónica de Veterinaria, 17: 1-21.

Glaessner, M.F. 1969. Decapoda. In: Moore, R.C. (Ed.). Treatise on invertebrate paleontology. Geological Society of America and University of Kansas Press, Kansas, pp. 399-532.

González-Gándara, C. 2011. La zona marina. In: CruzAngón, A. (Ed.). La biodiversidad en Veracruz: Estudio de Estado Veracruz, México. Comisión Nacional para el Conocimiento y Uso de la Biodiversidad (CONABIO), Gobierno del Estado de Veracruz, Universidad Veracruzana, Instituto de Ecología, Ciudad de México, pp. 293-300.

Gómez-Lemos, L., Cruz-Castaño, N. \& Duque-Nivia, G. 2010. Composición y estructura del ensamblaje de crustáceos Brachyura de la plataforma continental de Las Guajira colombiana y su relación con la profundidad y las características del sedimento. Boletín de Investigaciones Marinas y Costeras, 39: 359-379. doi: 10.25268/bimc.invemar.2010.39.2.154

Gracia, A. \& Mendoza, N. 2006. Aspectos de la biología de Portunus spinicarpus Stimpson 1871 (Decapoda: Portunidae) en el Golfo de Salamanca, Caribe Colombiano. Boletín de Investigaciones Marinas y Costeras, 35: 235-239.

Gracia, A., Vázquez-Bader, A.R., Arreguín-Sánchez, F., Schultz-Ruiz, L.E. \& Sánchez, J.A. 1997. Ecología de camarones peneidos. In: Flores-Hernández, D., Sánchez-Gil, P., Seijo, J.C. \& Arreguín-Sánchez, F. (Eds.). Análisis y diagnósticos de los recursos pesqueros críticos del Golfo de México. EPOMEX Serie Científica 7. Universidad Autónoma de Campeche, Campeche, pp.127-144.

Grainger, R.J.R. \& García, S.M. 1996. Chronicles of marine fishery landings (1950-1994): trend analysis and fisheries potential. FAO Fisheries Technical Paper, 359: 51 pp.

Hammer, O. \& Harper, D. 2003. PAST: paleontological statistics software package for education and data analysis, Version 1.15. [http://palaeo-electronica.org/ 2001_1/past/issue1_01.htm]. Reviewed: July 31, 2017.

Hermoso-Salazar, A.M. \& Arvizu-Coyotzi, K. 2007. Los estomatópodos y decápodos del Parque Nacional Sistema Arrecifal Veracruzano. In: Granados-Barba, A., Abarca-Arenas, L.G. \& Vargas-Hernández, J.M. (Eds.). Investigaciones científicas en el Sistema Arrecifal Veracruzano. Universidad Autónoma de Campeche, Campeche, pp. 101-112.

Hernández-Aguilera, J.L. \& Sosa-Hernández, P. 1982. Crustáceos decápodos y estomápodos en las costas de Tabasco y Campeche. Secretaría de Marina, Investigaciones Oceanográficas, 1: 1-117.

Hidobro-Campos, L., Lambarri-Martínez, C., HernándezCruz, D., Vallarta-Zarate, J.R. \& Rojas-González, R.I. 2021. Catálogo de especies: campaña sonda de Campeche. Instituto Nacional de Pesca y Acuacultura, Ciudad de México.

Jiménez, R. 1979. Características hidrográficas de la Vertiente del Golfo de México en el Estado de Veracruz. Investigaciones Geográficas, 9: 117-156. doi: 10.14350/rig.58917

López-Salgado, I. 1986. Estudio taxonómico de la familia Majidae (Crustacea-Decapoda-Brachyura) de la costa este de México. Tesis de Biología, Universidad Nacional Autónoma de México, Tlalnepantla.

Lui, K.K., Ng, J.S. \& Leung, K.M. 2007. Spatio-temporal variations in the diversity and abundance of commercially important Decapoda and Stomatopoda in subtropical Hong Kong waters. Estuarine, Coastal and Shelf Science, 72: 635-647. doi: 10.1016/j.ecss.2006. 11.023

Magurran, A.E. \& McGill, B.J. 2011. Biological diversity: frontiers in measurement and assessment. Oxford University Press, Oxford.

Margalef, R. 1974. Ecología. Ediciones Omega, Barcelona.

Matteucci, S.D. \& Colma, A. 1982. Metodología para el estudio de la vegetación. Secretaría General de la Organización de Estados Americanos, Programa Regional de Desarrollo Científico y Tecnológico. OEA, Washington.

McCaughran, D.A. 1992. Standardized nomenclature and methods of defining bycatch levels and implications. Proceedings of the national industry bycatch workshop. Natural Resources Consultants Inc., Oregon, pp. 200-201. 
McConnaughey, H.B. 1974. Introducción a la biología marina. Acribia, Zaragoza.

Morán-Silva, A., Martínez-Franco, L.A., Chávez-López, R., Franco-López, J., Bedia-Sánchez, C.M., Contreras, F., et al. 2005. Seasonal and spatial patterns in salinity, nutrients, and chlorophyll $\alpha$ in the Alvarado Lagoonal System, Veracruz, Mexico. Gulf and Caribbean Research, 17: 133-143. doi: 10.18785/gcr.1701.14

Morán-Silva, A., Chávez-López, R., Jiménez-Badillo, M.L., Cházaro-Olvera, S., Galindo-Cortes, G. \& Meiners-Mandujano, C.G. 2017. Análisis de la comunidad de peces de descarte en la pesca de arrastre de camarón (temporada de lluvias 2013) en la zona centro-sur del litoral veracruzano, México. Revista de Biología Marina y Oceanografía, 52: 551-566. doi: 10.4067/S0718-19572017000300012

Powers, L.W. 1977. A catalogue and bibliography to the crabs (Brachyura) of the Gulf of Mexico. Contributions in Marine Science, 20: 1-190.

Rodríguez-Almaraz, G.A., Leija-Tristán, A. \& Mendoza, R. 2000. Records of caridean shrimps (Crustacea: Decapoda) from the coast of the Mexican Pacific ocean, Gulf of Mexico and Mexican Caribbean. Bulletin of Marine Science, 67: 857-867.

Ruiz, T., Vázquez-Bader, A.R. \& Gracia, A. 2013. Asociaciones de megacrustáceos epibentónicos en la Sonda de Campeche, golfo de México. Revista Mexicana de Biodiversidad, 84: 280-290. doi: 10.7550/rmb. 27685

Secretaría de Agricultura y Desarrollo Rural-Instituto Nacional de Pesca (SAGARPA-INAPESCA). 2010. Dictamen técnico. Estimación de la fecha óptima para la apertura de la temporada 2010-2011 de la pesquería de camarón café (Farfantepeneaus aztecus) en las costas de Tamaulipas y Veracruz. Instituto Nacional de Pesca, Ciudad de México.

Sanvicente-Añorve, L., Gómez-Ponce, A., VázquezBader, A.R. \& Gracia, A. 2008. Morphometry and relative growth of the swimming crab, Portunus spinicarpus (Stimpson, 1871) from the southern Gulf of Mexico. Crustaceana, 81: 329-339. doi: 10.1163/ 156854008783564046

Scott-Denton, E., Cryer, P.F., Duffy, M.R., Gocke, J.P., Harrelson, M.R., Kinsella, D.L., et al. 2007. Characterization of the US Gulf of Mexico and south Atlantic penaeid and rock shrimp fisheries based on observer data. Marine Fisheries Review, 74: 1-27.

Setubal-Pires, A.M. 1992. Structure and dynamics of benthic megafauna on the continental shelf offshore of Ubatuba, southeastern Brazil. Marine Ecology Progress Series, 86: 63-76. doi: 10.3354/meps087063

Sokal, R.R. \& Rohlf, F.J. 2003. Biometry. W.H. Freeman, New York.
Sparre, P. \& Venema, S.C. 1995. Introducción a la evaluación de stocks de peces tropicales. Parte 1: Manual. Documento Técnico de Pesca, FAO, 306/1: $420 \mathrm{pp}$.

Vázquez-Bader, A.R. 1988. Comunidades de macroinvertebrados bénticos de la plataforma continental del suroeste del Golfo de México: abundancia, distribución y asociaciones faunísticas. Tesis de Magister, Universidad Nacional Autónoma de México, Ciudad de México.

Vázquez-Bader, A.R. \& Gracia, A. 1994. Macroinvertebrados bénticos de la plataforma continental del suroeste del Golfo de México. Universidad Nacional Autónoma de México, Ciudad de México.

Wakida-Kusunoki, A.T., Solana-Sansores, R., SandovalQuintero, M.E., Núñez-Márquez, G., Uribe-Martínez, J., González-Cruz, A. \& Medellín-Ávila, M. 2006. Camarón del Golfo de México y Mar Caribe. In: Arreguín-Sánchez, F., Beléndez-Moreno, L., GómezHumarán, I.M., Solana-Sansores, R. \& RangelDávalos, V. (Eds.). Sustentabilidad y pesca responsable en México, evaluación y manejo. Instituto Nacional de la Pesca, Secretaría de Agricultura, Ganadería, Desarrollo Rural, Pesca y Alimentación, Ciudad de México, pp. 427-476.

Wakida-Kusunoki, A.T., Becerra-de la Rosa, I., González-Cruz, A. \& Amador-del Ángel, L.E. 2013. Distribución y abundancia de la fauna acompañante del camarón en la costa de Tamaulipas, México (veda del 2005). Universidad y Ciencia, 29: 75-86.

Warwick, R.M. \& Clarke, K.R. 1991. A comparison of some methods for analyzing changes in benthic community structure. Journal of Marine Biology Association of United Kingdom, 71: 225-244. doi: 10.1017/S0025315400037528

Wells, R.D., Cowan Jr., J.H. \& Patterson III, W.F. 2008. Habitat use and the effect of shrimp trawling on fish and invertebrate communities over the northern Gulf of Mexico continental shelf. ICES Journal of Marine Science, 65: 1610-1619. doi: 10.1093/icesjms/fsn 145

Wicksten, M.K. \& Packard, J.M. 2005. A qualitative zoogeographic analysis of decapod crustaceans of the continental slopes and abyssal plain of the Gulf of Mexico. Deep-Sea Research I, 52: 1745-1765. doi: 10.1016/j.dsr.2005.04.006

Williams, A.B. 1966. Shrimps, lobsters and crabs of the Atlantic coast of the eastern United States, Maine to Florida. Smithsonian Institution Press, Washington DC.

Williams, A.B. 1974. The swimming crabs of the genus Callinectes (Decapoda: Portunidae). Fisheries Bulletin, 72: 685-798. 
Yáñez-Arancibia, A. 1986. Los peces demersales de la plataforma continental del Sur del Golfo de México. 1. Caracterización ambiental, ecología y evolución de las especies, poblaciones y comunidades. Universidad Nacional Autónoma de México, Ciudad de México.

Received: 18 May 2020; Accepted: 12 April 2021
Yañez-Arancibia, A., Lara-Domínguez, A.L., SánchezGil, P., Rojas-Galaviz, J.L. \& Alvarez-Guillén, H. 1988. Dinámica de las comunidades nectónicas costeras en el sur del Golfo de México. In: YañezArancibia, A. \& Day Jr., J.W. (Eds.). Ecología de los ecosistemas costeros en el sur del Golfo de México: la región de la Laguna de Términos. Universidad Nacional Autónoma de México, Ciudad de México, pp. 357-379. 